\title{
NEW HORIZONS: BEYOND TERRITORIALISM
}

\author{
Andreas Faludi \\ Professor Emeritus, Guest Researcher \\ Delft University of Technology \\ Oostplantsoen 114, 2611 WL Delft: The Netherlands \\ a.faludi@xs4all.nl
}

\begin{abstract}
Taking inspiration from maritime spatial planning, more in particular the Law of the Sea dividing ocean space into zones of graduated control, including areas beyond national jurisdiction (where by definition territorialism does not apply) the paper revisits territories as the building blocks of a political order. From there it proceeds to discussing the power, not to say the delusion of territorial sovereignty, only to revisit neo-medievalism as an alternative ordering principle for the governance of space. Accordingly, though sovereign in theory, stand-along territories are in reality conceptualised as being enmeshed in a web of functional relations, many of which with their own governance arrangements and with many overlaps between them. Which makes imposing an overall order a doubtful enterprise.
\end{abstract}

Keywords: Law of the Sea, maritime spatial planning, neo-medievalism, territorialism.

The ocean must therefore be regarded as the 'other', something that is not terra firma and something that is always to some degree unknowable.

Gee (2019, p.25)

\section{Introduction}

Growing up in landlocked countries, when a review of my "The Poverty of Territorialism: A Neomedieval View of Europe and European Planning" ("The Poverty of Territorialism") (Faludi, 2018) referred to a Portuguese 'liquid empire' (Cardoso, 2019) I pricked my ears. This suggested governance being fluid, just as Ehler, Zaucha and Gee $(2019$, p.2) say about maritime spatial planning "(...) dealing with a number of overlapping sea spaces, each of which has its very own constituting relationships." But they seem open to the suggestion that on land, too, spatial relations are more fluid than many make them to be.

Without access to the original sources on the 'liquid empire' in Portuguese, I turned to Bethencourt (2007) in a volume published at the $500^{\text {th }}$ anniversary of Vasco da Gama making landfall in India. Its significance goes beyond that of the seafaring adventure which fascinated me as a boy. The crowning event of Portugal's building its oceanic empire led to the attempt, by the authority of no less than the Pope, to carve up the, at that time still largely unknown, world between the Iberian powers. But can the sea, and can trade routes - the real assets that were the object of dispute with that other seafaring people, the Dutch - be owned? Fluid as it is, sea space cannot be bought or sold or divided up through contracts, the humanist Hugo de Groot - Grotius - argued. 
So, it "(...) could not be claimed by any party as an exclusive territory; it belonged to all and was free for anyone to navigate" (Onnekink \& Rommelse, 2019, p.81). Grotius thus created the legal concept of the Freedom of the Seas. "[T]he sea 'wants' to serve everyone, and it can do just that because it is apparently inexhaustible and not used up by any particular activities - at the time of Grotius at least - nor damaged by human use." (Gee, 2019, p.28).

The opposite to this doctrine of mare nostrum was mare clausum: state jurisdiction being exercised, if not over the high sea, then at least over coastal waters: the foundation of the Law of the Sea under which coastal states have jurisdiction over their marine spaces, but not over the ocean and its resources. The United Nations Convention on the Law of the Sea (UNCLOS) thus codifies a 3-mile, 12-mile and even 200-mile zone and the continental shelve as defining the limits of various degrees of control. In so-called areas beyond national jurisdiction (ABNJ) however, Grotius' principle of a common heritage of mankind applies, creating "(...) wholly new maps of the world and led to new theatres of conflict" (Gee, 2019, p.31).

Aiming to counter territorialism under which states parcel land surface into sovereign realms, I myself had turned, not to the Law of the Sea, but to Zielonka (2014) invoking the prospect of a neo-medieval Europe with less precisely demarcated areas of control. My drawing inspiration from the Middle Ages seems counter-intuitive. Most people will see them as the Dark Ages and invoking the prospect of a return to the Middle Ages as a doomsday scenario. In this spirit; Harris (2019) in "The Second Sleep" portrays an England 800 years after a great cataclysm in 2025 as much like in the Middle-Age: impoverished and bigoted.

This is not what Zielonka nor myself mean. What we do mean is national territories as the building blocks of a spatial order making room for - or one had better say, because states and territories do not disappear, being overgrown by - flexible and overlapping spatial governance arrangements. But Wilson (2017) made me realise that fuzzy arrangements have not ended in 1493, the conventional end of the Middle Ages. It was only in the early-19 $19^{\text {th }}$ century that they were replaced for good by the modernist system of sovereign states. To call the scenario pre-modern might be more accurate, therefore, but neo-medievalism is more eye-catching.

Yet, the sea lingers in my thoughts, making me curious about the governance of the Portuguese sea-borne empire. Bethencourt (2007) describes it as based on distant, discontinuous, and fragmented territories, the maintenance of which “(...) required an inter-regional mobilisation of resources, strong military assistance, common political ground, and an ethnic identity shared by the Portuguese communities." (p.197) Not a strong, unified state, "(...) empire is always improvised, formed by an ambiguous balance among central strategies, local initiatives, and political possibilities that are framed by opposing powers (...) [T] hese crucial aspects are avoided by the nationalistic approach, which confuses serious study with epic feeling and state propaganda." (Bethencourt, 2007, p.197-198). This could be said about the European Union (EU), too.

Elsewhere, my source describes the Portuguese empire also as a 'nebula of power'. This "(...) complex system, which operated through the transfer, adaptation, and integration of local institutions, was quite decentralised, consisting of a strong base, an adaptable intermediate level, and a competitive, quarrelsome, fragile regional top level, not to mention the different types of political affiliations and associations." (Bethencourt, 2007, p.200).

'Nebula of power' could be another trope for the EU. Indeed, a cloud of governance arrangements enveloping its members has been one of the metaphors for European governance in "The Poverty of Territorialism". This is not where the parallels end. Always in need of manpower, the Portuguese converted, integrated and mobilised natives in a strategy of forming alliances with the local elites. But at the local level "(...) there were many local institutions (...) which retained their traditional structures and mechanisms for collecting taxes." (Bethencourt, 2007, p.220). Do I smell subsidiarity? 


\section{Come Maritime Spatial Planning}

Zaucha (2018) wrote the first, thankfully positive review of "The Poverty of Territorialism", and so far others have not exactly contradicted him. Zaucha (2018) also put down the gauntlet to me to look at maritime spatial planning. Yes, a closer look could have borne fruit. When invoking the archipelago metaphor conceiving of EU member states as islands in a sea of functional relations, I had for instance been unaware of the meaning of archipelagos under the Law of the Sea. There, under conditions, archipelagos are treated as if they were one territory with a base line around them, more or less a sort of national border. Unaware of this, I viewed archipelagos as islands grouped together, not because they were part of one and the same state, but because of their forming a mirror for states that, though separate, were nothing like truly independent. Figuratively speaking, I said, they were swimming in a sea of functional relations, a fact which bounded them together.

With Zaucha having invited me to look at maritime spatial planning, when preparing my keynote at the conference on "Shaping Marine and Coastal Space" at Sopot (Poland) on 23-24 September 2019, I could have done worse than reading Zaucha and Gee (2019) on "Maritime Spatial Planning: Past, Present, Future". Discussions there were lively. I learned about Poland, a coastal state, taking a strong hand in maritime spatial planning, managing the areas within its territorial waters and its exclusive economic zone (EEZ). Like the demarcation of land borders, that of the EEZ can be problematic as we can see from watching Turkey and Libya and Greece, Cyprus and Israel in the Mediterranean.

Pyć (2019) gives an account of this division of the sea into such zones with states exercising graduated control, but not in ABNJ. Their use "(...) must be carried out in such a way as not to affect the interest of other States." (Pyć, 2019, p.380). But note that in his review of my book, Zaucha (2018) warns that one can imagine at the end of the day, some quasi-territorial borders. The sea bed is after all rich in much-coveted minerals.

I scoured relevant entries also in the "Handbook of Territorial Politics" (Detterbeck \& Hepburn, 2018), including about the governance on Antarctica (Dodds \& Hemmings, 2018). My interest in this last substantial terra nullius was stimulated also by Keane (2018) presenting his views on an emergent 'monitory' democracy, citing the sixth continent having a form of governance evoking comparison with Bethencourt's 'nebula of power'.

This remains to be explored, but in "The Poverty of Territorialism", I had identified the monopoly on the production of democratic legitimacy, always within their territories, as the strongest maybe the last - line of defence of the exalted role enjoyed by states. So it was interesting to hear about Keane (2018) and Bethencourt (2007) - not as the only ones - exploring alternative ways of organising democracy.

In what follows I draw further inspiration from explorations of maritime spatial planning and related readings. This comes in three parts. First, I have more queries about territories as the building blocks of a political order. Second, I discuss the power, or perhaps I had better say the delusion, of sovereignty. Third, I revisit neo-medievalism. The conclusions set out a further task, one that may well be beyond me: challenging the monopoly states enjoy on the production of democratic legitimacy. 


\section{An Ordering Principle}

In the "Handbook on the Geographies of Regions and Territories", Jessop (2018) discusses terrestriality, territoriality, and statehood. The former refers to the whole of terra, including the "(...) sea, its depths and the seabed, the air above, and, nowadays, outer space" and the object of territorialisation: throwing boundaries around territories. In so doing, territorialisation relies on territoriality: controlling movements across borders, in so doing defining territories. Success in doing so is, however, always relative. Be that as it may, exercising their territoriality, state divide "(...) the landmass (and nearby waters) into delimited areas governed by a political authority (...) Conversely, (...) the 'high seas' and some other terrestrial areas (notably the Antarctic) escape territorialisation." (Jessop, 2018, p.90). Indeed, as another author in the same volume reminds us, territory "(...) is a word frequently used to refer to an area of land claimed by a state, or to a "homeland" claimed by a national grouping seeking self-determination. Territoriality is normally seen as the actions or behaviours used to control or exert power over a geographically designated space." (Storey, 2018, p.34).

Jessop (2018) also recalls that throwing boundaries around states leads to 'methodological nationalism': the conflating of nation with society, as if nothing beyond its borders mattered. Likewise, methodological nationalism conflates its territory, bounded as it is, with the real thing: space and spatial relations unbounded, as they are. This is why all this has "(...) led to lively debates on the changing territorialities of statehood, including regionalism and cross-border regions as well as new forms of sovereignty and governance (...)" (Jessop, 2018, p.90). Read for all this territorialism as I define it in my book, following Scholte (2000, p.47) who defines it as macro social space being "(...) wholly organized in terms of units such as districts, towns, provinces, countries and regions. In times of statist territorialism more particularly, countries have held pride of place above the other kinds of territorial realms." The but of my criticism, I compare it with stacking containers into and above each other, with state containers the privileged building blocks of the whole edifice. Which shapes my view of nation-states, their history and ideology and their role in international relations.

This my understanding has been strengthened by revisiting the French author Thiesse (1999) showing that the creation of nations by awakening the consciousness of people of what is unique to their home area has been a nineteenth-century intellection fashion. Which is like Loriaux (2008) observing Romantics creating and subsequently spreading nationalism as an intellectual fashion and an export article. Maybe because he has succumbed to a fever in so doing, Lord Byron taking up the cause of Greek independence from Ottoman rule has been the emblematic example.

Not as the only one, Popescu (2012) reminds us that all this had been made possible by the Peace of Westphalia. It provided the impetus, first, “(...) for imagining territorially sharp border lines (...) The spatiality of state limits was reduced to a linear dimension. Second, it generalized the use of sharp territorial border lines (...)" (Popescu, 2012, p.34). All of which reflected new rationalist thinking, creating a unidimensional understanding of space:

Political-territorial borders (...) are only to be found following the emergence of nationalists and the institution of the nation-state. (...) Nationalism required an intimate connection between people and territory. The territorialization of identity materialized the nation. The institution of the state gave the nation its political expression. Boundaries served to bind it all together. They helped maintain domestic coherence (the coherence of the nation) and regulate interactions with other nations. (Popescu, 2012, p.35) 
Other than before when the aristocracy was the state, the claim to include everybody within its borders gave people a stake in it. Rather than subjects, they became citizens and the territory of the state the territory of the nation, with its borders becoming the borders of the nation. Invoking the whole tragedy of the twentieth century - and one can now say beyond - this author points to the original fallacy of nationalism "(...) to assume that people have common identities only because they happen to live inside the borders of a territory. Virtually all European states were composed of more than one national group." (Popescu, 2012, p.45). Nonetheless, state borders still hold a monopoly over geographic imaginations. Societies continue to be thought of, he continues, "(...) as contained by territorially linear state borders, and political independence cannot be imagined without state border lines. (...) What is absent (...) is the will to search for answers beyond borders and bordering, and perhaps to transcend borders and bordering altogether."

Looking beyond borders is presently the more necessary since, as a popular saying goes, environment knows no borders. So, that "(...) socially constructed border lines can contain the impact of human activity on the natural environment appears absurd. Yet modern state sovereignty suggests just this - a state is free to use the natural environment inside its borders in whatever way it pleases." (Popescu, 2012, p.53). A point to which I shall return discussing new-medievalism. First I discuss sovereignty.

\section{Underlying Fictions}

In their book "Maritime Spatial Planning, Past, Present, Future" edited with Zaucha, Gee (2019, p.25) says the ocean must " (...) be regarded as the 'other', something that is not terra firma and something that is always to some degree unknowable (...) a surface of difference." Gee (2019, p.24) says furthermore that relevant maps and planning documents obscure "(...) the continuous movement of water that makes it impossible to truly locate a point in the ocean as a permanent material place." Which reminds of pre-modern times when frontiers were fluid zones of transition rather than sharp lines, a characteristic to some extent shared by their modern equivalents. After all, Popescu (2012, p.65) already quoted says: "State border lines do not provide a sufficiently effective framework for addressing some of the major issues affecting twenty-first century societies. The territorial scope of these issues requires that they be regulated by different types of borders." So we might just as well draw inspiration from looking at the ocean and at maritime spatial planning.

Indeed, the predominant linear type of borders requires rethinking. Borders must change, depending on the issues at hand, making for overlapping action spaces. But flexible regimes dealing with flexible spaces run foul of the principle of states exercising sovereignty over their territory, but not beyond. The very existence of spaces, functional or otherwise, straddling borders challenged state sovereignty, and particularly so where such spaces are becoming institutionalised, opening up "(...) innovative ways of conceiving of judicial affairs positioned beyond the traditional legal systems (...)" (Popescu, 2012, p.142).

Which is only too true for the story of the EU, better to say the European Commission acting on behalf of it, proposing novel ideas in the context of pursing its cohesion policy. With great inventiveness, it thus challenges the territoriality of member states (Faludi, 2016). Which is also and in particular true for cross-border and transnational planning. But, on grounds of principle, and however modest, proposals to allow for the transfer of elements of sovereign rule so as to facilitate cross-border cooperation meet with suspicion and principled resistance. But the problems 'on 
the ground', as it were, do not lend themselves to being dealt with within the territorial confines. "Institutional regions have precise boundaries, defined powers and belong to nation states. Spatial regions, by contrast, have fuzzy powers, informal derivative powers and may span across nation states. 'Regionalization' - the process through which regions develop or acquire new prominence - is therefore a polysemic word." (Piattoni, 2016, p.75). Expert on multi-level governance, a concept coined with reference to EU regional policy, this author relates this to hard and soft places and to 'flexible territoriality' coupled with the 'pooling of sovereignty'. She also points out that the Commission pursues a deliberate policy favouring subnational and transnational formations in its many efforts to jump-start European integration.

Writing on what is called 'relational thinking' in political geography, invoking Allmendinger, Haughton, Knieling and Othengrafen (2015), Cochrane (2018, p.86) points out that in presentations of plans to, or on behalf of governments, a "(...) border will appear on maps, but in thinking about development strategies ... the fuzziness of borders will play a greater part (...)". Indeed, planners have to look at the 'real thing' never fully enclosed by borders as it is.

Which is why planning landside is not so different from planning seaside. Its object may seem more solid, more amenable to being arranged in boxes but, taking account of functional relations, it becomes fuzzy. After all, relations are more fluid, more difficult to pin down than one may think. Which is like the ocean of which once again Gee $(2019, p .24)$ says it is the unknowable 'other' of which maps and planning documents "(...) suggest a false sense of the static, obscuring the continuous movement of water that makes it impossible to truly locate a point in the ocean as a permanent material place." The point is: taking account of the true intricacies of spatial relations, this is as true of maps and how to read, let alone to act upon them. We should not be fooled by notions of sovereignty into believing that there is a natural, safe, uncontroversial object of planning, a given territory which can, and must be managed on behalf of a unified people.

For all these reasons, is the idea that, due to their democratic mandates, state authorities are the legitimate representatives of their peoples, each assumed to be homogenous not another fiction? If so, then nonetheless a potent one. And we see states even reasserting their mandates, acting on behalf of a people assumed to be a law to itself. But maybe it is in fact the other way round! Maybe state authorities, and above all elected representatives, in fact the whole, what I have once described as the 'Territorial-Administrative Complex' (Faludi, 2016) merely invokes the argument to justify its hold on power?

It is in this context that the role and concerns of what is called 'areas left behind' might also be addressed briefly. Dijkstra, Poelman and Rodríguez-Pose (2019) demonstrate that living in such an area, and not age, education or poverty is the outstanding factor behind anti-establishment voting against allegedly rootless elites, the 'anywheres', as Goodhart (2017) has called them. But, even if they had the genuine desire to do so, anti-establishment movements or parties may be unlikely to address the grievances of areas left behind. The reason is that territorialism generates what one might call a 'false consciousness' that 'taking back control' of one's territory is the solution. Which is why, paraphrasing Karl Marx, in "The Poverty of Territorialism" I have likened territorialism, and the associated idea of sovereignty over territory, to 'opium for the people'.

\section{Neo-medievalism}

As indicated, in "The Poverty of Territorialism" I propose to look at Europe and European spatial planning as being 'neo-medieval'. Quoted before and also further below, without ever mentioning the term, Popescu's (2012) analysis of the changing nature of borders points in the same direction: 
if neo-medieval means overlapping, rather than clearly delineated spaces as the objects of policy and planning, then there is much support for neo-medievalism to be gained from looking at practice.

Think for instance of what is called land-sea interaction (LSI), the object of a new so-called targeted analysis by the European Spatial Observation Network ESPON (ESPON, 2019). LSI cuts across legal and administrative boundaries between the land and the sea. After all, those boundaries notwithstanding, what takes place in the marine environment has an onshore component, or impact, and vice versa. Which requires taking a comprehensive approach, what the ESPON report calls a 'one-space' land/sea view. For this the report invokes the term 'territorial planning'. After all that's said above, the term does not appeal to me. In my book, in a rhetorical as well a literal sense of the word, territorial planning is planning in, and of administrative territories relying, be it directly or indirectly, on the sovereign powers of the state.

The intention of the authors of the report is clearly not to restrict planning in this way. Rather, it is for planning to articulate, and subsequently deal with problems as they occur 'on the ground', so to speak, and this ground criss-crosses the coast line where land and sea, each with its own regimes interact. Which is what 'one-space' land/sea view means: to reflect the true nature and extent of problems, in this case at the interface between land and sea. So, this is the opposite of planning bounded by the borders of a jurisdiction. In this sense, the report asks for identifying the relevant space - once again in my terms misrepresented as a territory - based on the real interdependence between what's happening on land and in the adjoining sea space. This it describes as the 'one-space' view and the key to better address LSI by integrating marine spatial and terrestrial planning (ESPON, 2019, p.3).

Applying the LSI perspective will result, not in one plan but in as many plans as there are types of interaction between what's happening on the land and the sea. The picture emerging is therefore likely to be one of overlapping planning areas. Which in turn will lead to - in the, for the purposes of this article unhelpful terminology - 'territorial planning' taking many forms and shapes with overlaps, reflecting the real complexity of the interaction between the land and the sea.

Many of the issues will relate to the management of the environments along seashores. But as the saying about environment generally goes: it knows no borders. Which means that planning for environmental protection and development, not only along the coast line, but all around must cut across administrative borders. Starting very generally by saying that it is "(...) important to appreciate just how much of political life cuts across the 'vertical' divisions of the formal hierarchy", Meadowcroft (2002, p.171) continues: "All sorts of political problems cross jurisdictions; feelings of identity coincide only approximately with established borders, while common interests and concerns unite geographically remote constituencies. Many organisations (...) find themselves acting in political 'spaces' which cut across conventional boundaries. And territorially rooted institutions are constantly being stretched to engage with issues which escape their jurisdiction or infiltrate their frontiers."

Pursuing this further, he says that established governmental hierarchies are unable to cope and that environmental governance is "(...) likely to remain radically disjointed, with disparate sets of structures pre-occupied with impacts at varied and cross-cutting scales." (Meadowcroft, 2002 , p.177). And he holds out no hope for this to be substantially different in future: "The patterns of economic, cultural and environmental interdependence (...) are simply too diverse, intricate, and rapidly changing (...)" (p.177). Which relates to Popescu (2012) already quoted, much as to my concerns in "The Poverty of Territorialism". Suffice it to say, Popescu $(2012$, p.153) concludes by drawing attention to what he calls a "(...) major twenty-first century paradox that found expression in the desire to cross all borders while at the same time desiring to erect borders of all kinds 
and shapes. This paradox has invited considerable border-making tensions between simultaneous demands for unimpeded cross-border mobility on the one hand and for reliable territorial security on the other."

The upshot is that borders have had to be redefined, leading to their differentiation - and here the parallels with LSI and environmental governance become evident - according to function: "While some border lines in some places are dismantled or have their barrier functions significantly diminished, other borders in other places are erected. These new borders often do not maintain a linear appearance and are not located at the margins of a state's territory." (Popescu, 2012, p.153). Which is of course grist for my mill where I cast doubt on the continuing validity of modernist ideas about the nation-state and its control over territory: Since borders are constitutive for territories, the very configuration of territory, indeed, our understanding of what territory is, will have to be adapted through de- and reterritorialisation, Popescu says. The outcome cannot fail to be close to the neo-medievalism which, taking a leaf out of the book, already mentioned, by Zielonka (2014) I invoke in "The Poverty of Territorialism".

His main concern being regionalism, Keating (2012) also invoked neo-medievalism in anything but in name. Having announced the 'end of territory', he notes geographers and others having failed to take account of reterritorialization and spatial rescaling and the new regionalism, with the $\mathrm{EU}$ and cross-border regions or spaces straddling several states being his case in point. "European integration has been presented as a form of deterritorialization and border transcending and thus a deeper and specific example of globalization, while simultaneously representing a form of reterritorialization and boundary-drawing at a new level." (p.38). More in particular, he says: "European integration is creating new territorial boundaries for some purposes and not others so that, while states may be losing their old monopolies, this does not necessarily herald the emergence of an integrated European space to replace them. Europe is not so much suppressing state borders as changing their meaning and impact (...)" (Keating, 2009, p.38).

Which implies a new political and spatial order much like Zielonka's neo-medieval one. Without invoking neo-medievalism, Keating invokes the trope explaining this spatial order: "Functional, political and institutional spaces may partially overlap, but they rarely perfectly coincide in the manner envisaged in ideal-typical conceptions of the nation-state. Nor is there even a new spatial hierarchy or nested system of collective action, as in the traditional federal state." (2009, p.40).

Popescu (2012) goes more deeply into how this plays itself out at borders where various differentiated regimes exist. Others, like Besson (2004) and Kahn (2014) explore what this means for sovereignty, already discussed. It can no longer be absolute but must be cooperative, taking account of other people and concerns. Which is of course so with neighbours, but also as it were worldwide.

\section{After Territorialism}

At a time of growing nationalism, it seems counter-intuitive to say it, but in our world, more interconnected than ever, territorialism should have had its day. How come I say this when the EU members seem to once again embrace territorialism? But they are ill-advised in doing so. Global networks will have a field day taking advantage of them. Short of cutting back on migration, trade, international scientific research and cooperation in facing global challenges, a strategy that would lead to impoverishment, there is no other way but to face the world-as-it-is: growing together, not into one comprehensive whole, but becoming a complex bundle. 
Which is why the conventional, if idealistic answer: to aim for some form of federation - ultimately for world governance - takes us into a dead end. Ordering the world we must not reduce its complexity but accept it. Whatever its democratic mandate, one single authority could never manage it. The governance of ABNJ highlights the point. Pyć (2019, p.380) points out that, for as long as "(...) carried out in such a way as not to affect the interests of other States' its use is free for all." The "(...) natural unity of the World Ocean can be protected through the effective cooperation of all actors of the international community. The duty to cooperate is a fundamental norm in the legal context of the marine environment's protection." (Pyć, 2019, p.382). True, but what follows sound like a planner's dream: "Science-based, integrated, adaptive strategic and participatory approaches are all core values the IOC [International Oceanographic Commission - AF] promotes in the context of MSP." (Pyć, 2019, p.383). Which sounds like a blueprint for comprehensive planning. That, in turn assumes some supreme wisdom.

The next section on "An Effective Approach to Ocean Governance" confirms the belief in the virtues and sheer feasibility of such planning, eulogising an “(...) integrated, interdisciplinary, cross-sectoral and ecosystems approach to ocean governance" (Pyć, 2019, p.384). Might one read this as a plea for creating an agency responsible, most likely of the UN, endowed with commensurate powers? Embracing the ecosystems approach as "(...) a public process of analyzing and allocating the spatial and temporal distribution of human activities in marine areas to achieve ecological, economic, and social objectives (...)" (Pyć, 2019, p.387), is the IOC slated to be that agency? Be that as it may, without further explanation, Pyć adds that such objectives are usually specified through a political process.

The parallel with planning on land is only too obvious. This the more so since on the same page the author adds that in practice, “(...) the implementation of MSP may be burdened with ballast resulting from the sectoral approach and well-established habits when it comes to designating the competence of the administrative bodies responsible for maritime affairs."(Pyć, 2019, p.387). All of which reads like a handbook for (technocratic) planning. The mention of international lawyers considering whether the essentially still sectoral approach of UNCLOS could be turned into an integrative approach based on the notion of the oceans as mankind's common heritage enforces the point. What is implied is beyond comprehension: one overall authority responsible.

\section{References}

Allmendinger, Ph., Haughton, G., Knieling, J., \& Othengrafen, F. (Eds.). (2015). Soft Spaces in Europe: Re-negotiating Governance Boundaries and Borders. London: Routledge.

Besson, S. (2004). Sovereignty in conflict. European Integration Online Papers, 8(15), pp. 52.

Bethencourt, F. (2007). Political configurations and local powers. In: F., Bethencourt, \& D. R., Curto (Eds.). Portuguese Oceanic Expansion, 1400-1800 (pp. 197-254). Cambridge: Cambridge University Press.

Cardoso, R. V. (2019). The Poverty of Territorialism. Planning Theory \& Practice, 20(4), 622-624. https:// doi.org/10.1080/14649357.2019.1653004

Cochrane, A. (2019). Relational thinking and the region. In: A., Paasi, J., Harrison \& M., Jones (Eds.). Handbook on the Geographies of Regions and Territories (pp. 79-88). Cheltenham, Northampton, MA: Edgar Elgar.

Detterbeck, K., \& Hepburn, E. (2018). Handbook of Territorial Politics. Cheltenham, Northampton, MA: Edgar Elgar.

Dijkstra, L., Poelman, H., \& Rodríguez-Pose, A. (2019). The geography of EU discontent. Regional Studies. https://doi.org/10.1080/00343404.2019.1654603

Dodds, K., \& Hemmings, A. D. (2018). Arctic and Antarctic regionalism. In: A., Paasi, J., Harrison \& M., Jones (Eds.). Handbook on the Geographies of Regions and Territories (pp. 489-503). Cheltenham, Northampton, MA: Edgar Elgar. 
Ehler, C., Zaucha, J., \& Gee, K. (2019). Maritime/Marine Spatial Planning at the Interface of Research and Practice. In: J., Zaucha \& K., Gee (Eds.). Maritime Spatial Planning, Past, Present, Future (pp. 1-21). London, Cham: Palgrave Macmillan. https://doi.org/10.1007/978-3-319-98696-8_1

ESPON (2019). MSP-LSI - Maritime Spatial Planning and Land-Sea Interactions. Targeted Analysis: Draft Final Report. Retrieved from https://www.espon.eu/sites/default/files/attachments/MSP-LSI\%20 Draft\%20Final\%20Report\%2012\%20June\%202019.pdf

Faludi, A. (2016). European integration and the Territorial-Administrative Complex. Geografiska Annaler: Series B, Human Geography, 98(1), 71-80. https://doi.org/10.1111/geob.12090

Faludi, A. (2018). The Poverty of Territorialism: A Neo-medieval View of Europe and European Planning. Cheltenham, Northampton: Edward Elgar.

Gee, K. (2019). The Ocean Perspective. In: J., Zaucha \& K., Gee (Eds.). Maritime Spatial Planning, Past, Present, Future (pp. 23-45). London, Cham: Palgrave Macmillan. https://doi.org/10.1007/978-3319-98696-8_2

Goodhart, D. (2017). The Road to Somewhere: The Populist Revolt and the Future of Politics. London: Hurst \& Co.

Harris, R. (2019). The Second Sleep. London: Hutchinson.

Jessop, B. (2018). The TPSN schematic: moving beyond territories and regions. In: A., Paasi, J., Harrison \& M., Jones (Eds.). Handbook on the Geographies of Regions and Territories (pp. 89-101). Cheltenham, Northampton, MA: Edgar Elgar.

Kahn, S. (2014). The nation-state as a territorial myth of European Construction. L'espace géographiqie, 43(3), 220-230. https://doi.org/10.3917/eg.433.0240

Keane, J. (2018). Power and Humility: The Future of Monitory Democracy. Cambridge: Cambridge University Press.

Keating, M. (2009). Rescaling Europe. Perspectives on European Politics and Society, 10(1), 34-50. https://doi.org/10.1080/15705850802699995

Keating, M. (2012). Rethinking autonomy in a divided society. In: A.-G., Gagnon, \& M., Keating (Eds.). Rethinking Autonomy in a Divided Society: Imagining Alternative Democracies in Complex Settings (pp. 13-32). Houndsmill, Basingstoke, Hants: Palgrave Macmillan.

Loriaux, M. (2008). European Union and the Deconstruction of the Rhineland Frontier. Cambridge: Cambridge University Press.

Meadowcroft, J. (2002). Politics and scale: Some implications for environmental governance. Landscape and Urban Planning, 61(2/4), 169-179. https://doi.org/10.1016/S0169-2046(02)00111-1

Onnekink, D., \& Rommelse, G. (2019). The Dutch in the Early Modern World: A History of a Global Power. Cambridge: Cambridge University Press.

Piattoni, S. (2016). Exploring European Union macro-regional strategies through the lens of multilevel governance, In: S., Gänzle \& K., Kern (Eds.). A 'Macro-regional' Europe in the Making: Theoretical Approaches and Empirical Evidence (pp. 76-97). Houndsmill, Basingstoke, Hants: Palgrave Macmillan.

Popescu, G. (2012). Bordering and Ordering in the Twenty-first Century: Understanding Borders. Lanham, Boulder, New York, Toronto, Plymoth: Rowman Littlefield.

Pyć, D. (2019). The role of the law of the sea in maritime spatial planning. In: J., Zaucha \& K., Gee (Eds.). Maritime Spatial Planning, Past, Present, Future (pp. 375-395). London, Cham: Palgrave Macmillan.

Scholte, J.A. (2000). Globalization: A Critical Introduction. Houndsmill, London: Macmillan Press.

Storey, D. (2018). Territory and territoriality. In: A., Paasi, J., Harrison \& M., Jones (Eds.). Handbook on the Geographies of Regions and Territories (pp. 34-43). Cheltenham, Northampton, MA: Edgar Elgar. Thiesse, A.-M. (1999). La Création des identités nationales. Paris: Édition Seuil.

Wilson, P.H. (2017). The Holy Roman Empire: A Thousand Years of European History. London: Penguin.

Zaucha, J. (2018). Book review: The Poverty of Territorialism: A Neo-medieval View of Europe and European Planning. Europa XXI, 35, 127-131. https://doi.org/10.7163/Eu21.2018.35.8

Zaucha, J., \& Gee, K. (Eds.) (2019). Maritime Spatial Planning, Past, Present, Future. London, Cham: Palgrave Macmillan.

Zielonka, J. (2014). Is the EU Doomed? Cambridge: Polity Press. 